\title{
JURNAL ARSITEKTUR
}

VOLUME

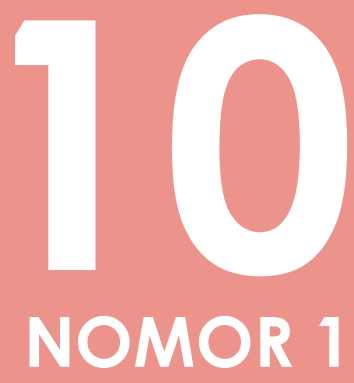

EDISI JANUARI 2020

ISSN 2087-2739 


\section{JURNAL ARSITEKTUR}

Terbit dua kali setahun pada Bulan Januari dan Juli. Diterbitkan oleh Program Studi Arsitektur Fakultas Teknik Universitas Bandar Lampung. JURNAL ARSITEKTUR merupakan media pendokumentasian, sharing, dan publikasi karya ilmiah yang berisi karya-karya riset ilmiah mengenai bidang ilmu perancangan arsitektur dan bidang ilmu lain yang sangat erat kaitannya seperti perencanaan kota dan daerah, desain interior, perancangan lansekap, dan sebagainya.

ISSN: 2087-2739

\section{PELINDUNG}

Prof. Dr. Ir. H.M. Yusuf Barusman, M.B.A. (Universitas Bandar Lampung)

\section{PENASEHAT}

Dr. Ir. Hery Riyanto, M.T. (Universitas Bandar Lampung)

\section{PENANGGUNG JAWAB}

Ir. Tjetjeng Sofjan S., M.M., M.T. (Universitas Bandar Lampung)

\section{PIMPINAN REDAKSI}

Dr.Eng. Haris Murwadi, S.T., M.T.

\section{REDAKSI PELAKSANA}

Shofia Islamia Ishar, S.T., M.T.

Ai Siti Munawaroh, S.Pd., M.I.L.

Dadang Hartabela, S.T., M.T.

Indyah Kumoro Wardani, S.T., IAI

\section{DEWAN REDAKSI}

Prof. Dr. Julaihi Wahid (Universitas Sains Malaysia)

Prof. Dr. Ir. H. Slamet Tri Sutomo, M.S (Universitas Hasanuddin)

Prof. Ir. Totok Rusmanto, M.Eng. (Universitas Diponegoro)

Dr. Ing. Ir Gagoek Hardiman. (Universitas Diponegoro)

Dr.Eng. Fritz Akhmad Nuzir, S.T., M.A.(L.A.) (Universitas Bandar Lampung)

David Hutama, ST., M.Eng (Universitas Pelita Harapan)

\section{MITRA BESTARI}

Dr. Ir. Budi Prayitno, M.Eng. (Universitas Gajah Mada)

Dr. Eng. Ir. Ahmad Sarwadi, M.Eng (Universitas Gajah Mada)

Dr. T. Yoyok Wahyu Subroto, M.Eng. Ph.D. (Universitas Gajah Mada)

Prof. Ir. Liliany Sigit Arifin, M.Sc., Ph.D (Universitas Petra)

Dr. Budi Faisal (Institut Teknologi Bandung)

Dr.Eng. Agus Hariyadi, S.T., M.Sc. (Universitas Gajah Mada)

\section{TIM GRAFIS DESAIN}

B. Chrysvania Artemisia

\section{ALAMAT REDAKSI}

Program Studi Arsitektur, Fakultas Teknik, Universitas Bandar Lampung Jalan Zainal Abidin Pagar Alam Nomor. 26 Labuhanratu, Bandarlampung, 35142

Telp. : : :0721-773847

E-mail : : editor.j@ubl.ac.id

Homepage $\quad:$ http://jurnal.ubl.ac.id/index.php/ja 


\section{Daftar Isi Artikel}

01-06 Tipologi Grid Kolom Pada Lamban Pekon Hujun di Lampung Barat LESTARI, A. Dwi Eva; FADHILI, M. Afif

07-18 Studi Evaluasi Pasca Huni Ditinjau dari Aspek Fungsional pada Bangunan Asrama Mahasiswa Putra (TB2) Institut Teknologi Sumatera (ITERA) KUSTIANI, MUNAWAROH, Ai Siti

19-28 Optimasi Komponen Fasad Menggunakan Generative Algorithm Studi kasus: ITERA Lampung KHIDMAT, Rendy Perdana; ULUM, M. Shoful; LESTARI, Dwi Eva, FUKUDA, Hiroatsu

29-34 Kenyamanan Termal Pada Obyek Wisata Berkembang (Studi Kasus: Obyek Wisata Blue Lagoon Yogyakarta) NURHADI, Septi Kurniawati

35-42 Analisis Ekspektasi Mahasiswa Terhadap Kota ARTEMISIA, B. Chrysvania; MUNAWAROH, Ai Siti; MURWADI, Haris

43-56 Kode Biner Sebagai Konsep Gubahan Perancangan Fasad Bangunan Studi Kasus: Redesign Gedung B Fakultas Teknik Universitas Lampung WIBAWA, M. Shubhi Yuda 


\title{
Tipologi Grid Kolom Pada Lamban Pekon Hujung di Lampung Barat
}

\author{
A. Dwi Eva Lestari ${ }^{1 *}$, M. Afif Fadhili ${ }^{2}$ \\ ${ }^{1}$ Prodi Arsitektur, Jurusan Teknologi Infrastruktur dan Kewilayahan, Institut Teknologi Sumatera \\ ${ }^{2}$ Prodi Arsitektur, Jurusan Teknologi Infrastruktur dan Kewilayahan, Institut Teknologi Sumatera \\ *Penulis Korespondensi: dwi.lestari@ar.itera.ac.id; Telp. +62 81360860360
}

\begin{abstract}
Abstrak:
Lamban merupakan sebutan untuk rumah tinggal vernakular di Pekon Hujung yang saat ini telah mengalami perubahan bentuk. Perubahan yang terjadi dipengaruhi oleh perkembangan zaman, tuntutan kebutuhan hidup serta pola kebiasaan pemilik rumah yang telah berubah. Perubahan bentuk lamban di Pekon Hujung menjadi permasalahan utama sehingga perlu dikaji terutama dari tipologi bentuk lamban yang ada di Pekon Hujung bertujuan untuk mengetahui perubahan yang terjadi, persamaan dan perbedaan bentuk, serta mengklasifikasikan tipe dari setiap jenis perubahan lamban di Pekon Hujung, dimana perbedaan dan persamaan yang paling terlihat secara fisik adalah besar-kecilnya massa dan ukuran bangunan berdasarkan pola grid kolom. Penelitian dilakukan dengan metode kualitatif berupa survey, observasi dan wawancara mendalam untuk mendapatkan pola dan bentuk grid kolom dari setiap lamban. Hasil penelitian menunjukkan 5 tipe rumah dengan 14 jenis pola grid kolom yang masih dapat terus bertambah. Hal tersebut menarik dimana biasanya perbedaan massa setiap rumah tradisional dipengaruhi kasta atau peraturan adat tertentu, sedangkan pada lamban Pekon Hujung ini hanya terbatas pada kemampuan finansial setiap penghuninya untuk membangun rumah sesuai dengan kebutuhannya
\end{abstract}

Kata Kunci: Lamban Lampung Barat; Pekon Hujung; Tipologi grid kolom.

\section{Latar Belakang}

Pekon merupakan sebutan untuk desa atau kampung dalam Bahasa Lampung. Pekon Hujung berarti "desa ujung" yang tepatnya berada di Kecamatan Belalau, dibagian ujung Kabupaten Lampung Barat Provinsi Lampung, yang berbatasan langsung dengan Oku Selatan Provinsi Sumatera Selatan. Berpenduduk sekitar 6000 jiwa dengan jumlah kepala keluarga sebanyak $1300 \mathrm{KK}$, masyarakat Pekon Hujung masih menggunakan lamban khas berbentuk panggung dan bermaterial kayu sebagai rumah tinggal, meskipun terlihat banyak perbedaan bentuk antara satu lamban dengan lamban lainnya di Pekon Hujung.

Potensi lokal yang dimiliki serta bertumbuhnya arsitektur rakyat dengan memadukan segala macam perubahan tradisi merupakan jawaban dari makna arsitektur vernakular lamban Pekon Hujung. Keberagaman bentuk dari lamban di Pekon Hujung membuat seolah tidak adanya kesamaan dari setiap rumah dan melupakan adat ataupun tradisi setempat. Oleh karena itu, penting adanya klasifikasi agar mengetahui persamaan dan perbedaan setiap rumah dengan cara melakukan kajian tipologi dari lamban-lamban di Pekon Hujung. Sementara secara sederhana tipologi dapat diartikan sebagai kegiatan pengelompokan objek berdasarkan struktur formal yang sama (Moneo, Raphael 1978).

\section{Metode}

Dalam menjawab permasalahan penelitian digunakan metode kualitatif dengan cara mengumpulkan data lapangan kemudian mengolah serta menganalisis data yang diperoleh, kemudian dijabarkan dalam hasil pembahasan sebelum ditarik kesimpulan dari hasil penelitian.

\subsection{Metode Pengumpulan Data}

Metode pengumpulan data yang digunakan adalah dengan melakukan survei lapangan, observasi dengan cara melihat, mengamati, merekam dan melakukan pengukuran pada lamban Pekon Hujung sebagai objek amatan, serta melakukan wawancara dengan narasumber sebagai pendukung data.

\subsection{Metode Analisis Data}

Setelah data terkumpul selanjutnya dilakukan analisis data yang berfokus pada penggambaran grid-grid kolom dari setiap lamban yang teramati berikut merangkum hasil wawancara dengan pemilik rumah, pemangku desa setempat serta tokoh masyarakat Pekon Hujung. Hasil pembagian yang didasarkan pada tipologi grid kolom digambarkan dalam tabel pembanding dalam bab hasil dan pembahasan. 


\section{Hasil dan Pembahasan}

Hasil observasi memperlihatkan banyak tipe rumah dengan berbagai perubahan detailnya, mulai dari perubahan bentuk dan fungsi ruang bawah/kolong lamban, perubahan fasad, perubahan material serta penambahan ruang-ruang terutama ke arah belakang maupun toilet yang sebelumnya belum ada menjadi ada. Meskipun begitu, jika diperhatikan lebih jauh lagi ternyata lamban ini memiliki pola tersendiri yang kemudian perlahan berubah berdasarkan keinginan pemilik/penghuninya. Pola yang paling terlihat untuk dijadikan pembanding dari lamban Pekon Hujung ini yakni tipologi grid kolom. Grid merupakan suatu pola berulang dari bentuk sederhana seperti persegi, persegi panjang maupun segi banyak. Grid kolom yang dimaksud pada penelitian ini ialah penggunaan sistem kolom yang berbentuk segi 4 sebagai penopang struktur bangunan.

Tabel 1. Tipologi Grid Lamban Pekon Hujung

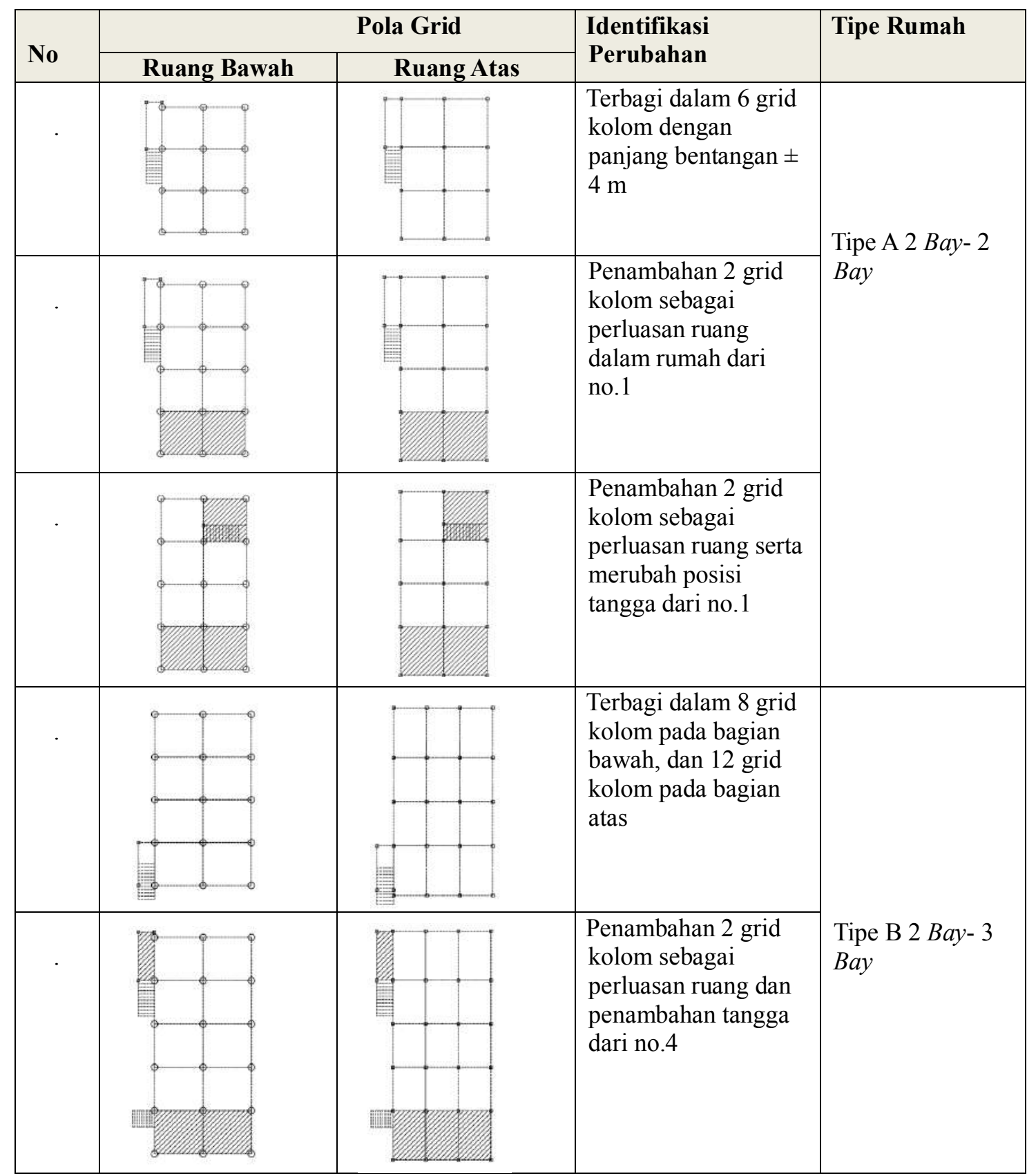




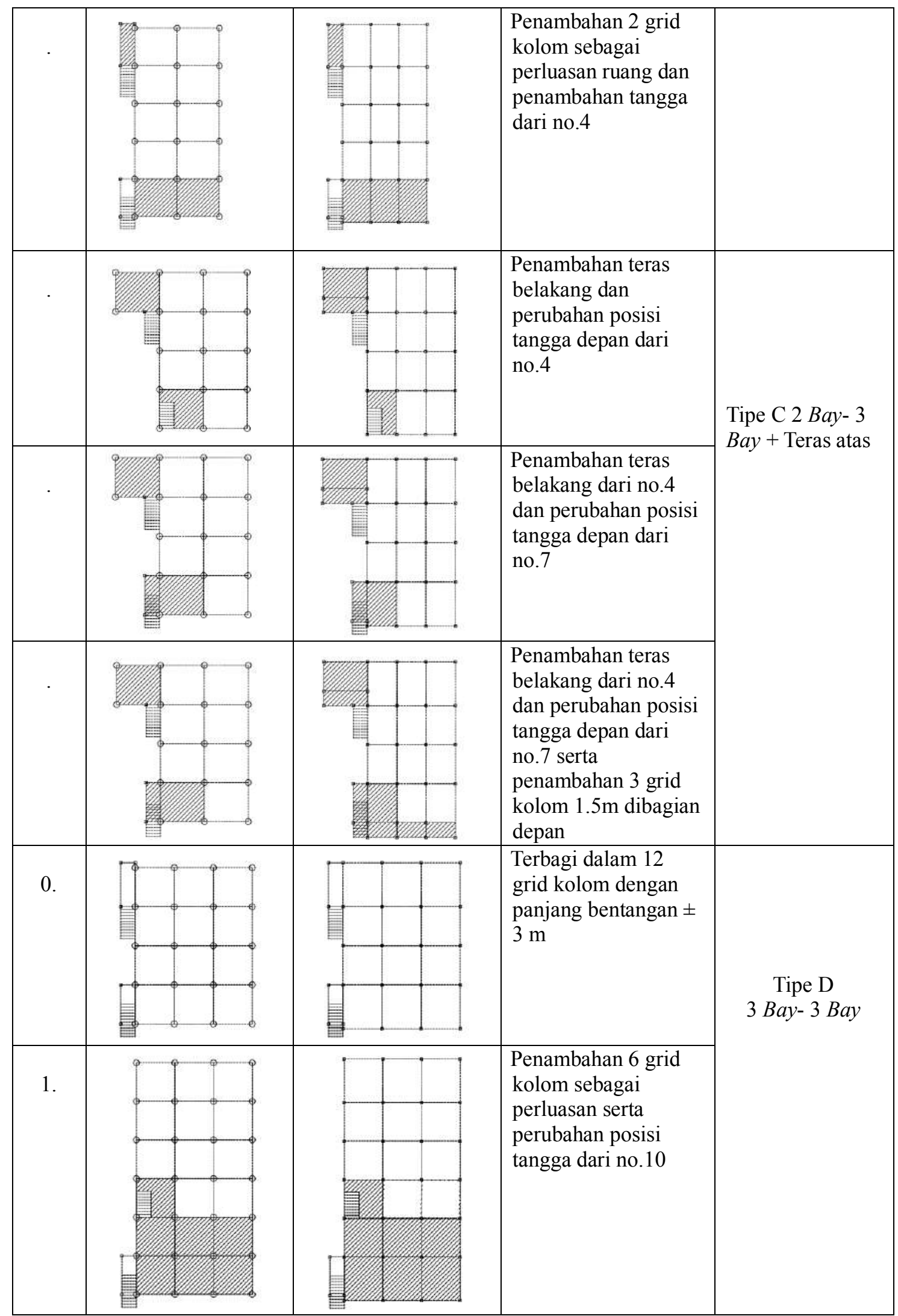




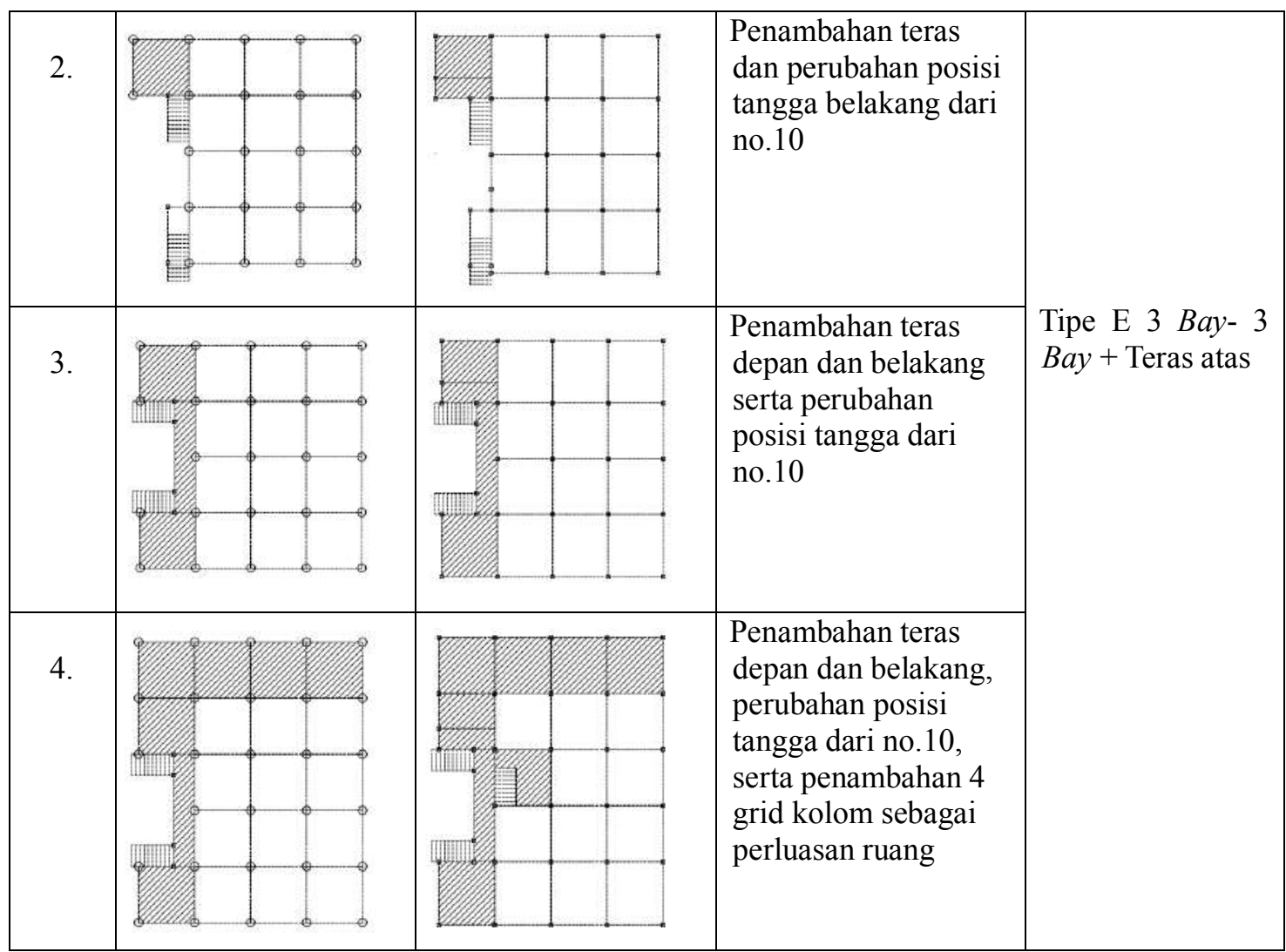

Berdasarkan data tabel diatas terlihat bahwa lamban Pekon Hujung terbagi dalam 5 tipe rumah dengan 14 jenis grid kolom, dan ada kemungkinan grid tersebut akan bertambah seiring bertambahnya kebutuhan penghuni rumah di masa mendatang. Perkembangan morfologi grid kolom terlihat pada sistem bay. Sistem bay yang dimaksud adalah pembagian pola ruang secara horizontal dari sisi kanan dan kiri bangunan.

Bentang grid kolom $\pm 3 \mathrm{~m}$ untuk tipe 2 bay dan $\pm 4,5 \mathrm{~m}$ untuk tipe 3 bay, panjang bentangan dipengaruhi dari bentang kayu yang tersedia didaerah tersebut. Jika dahulu panjang kayu bisa mencapai $9 \mathrm{~m}$, sekarang sudah sangat sulit untuk mencari yang lebih panjang dari $4 \mathrm{~m}$.

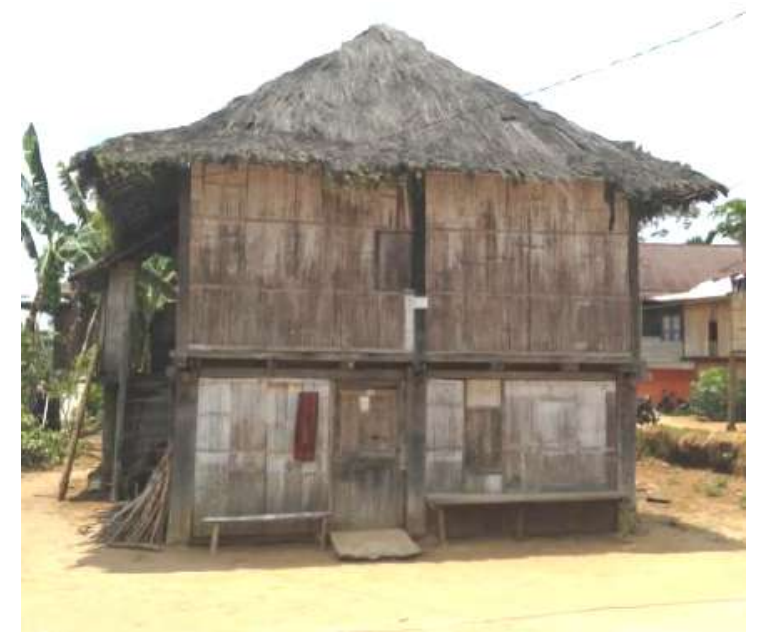

Gambar 1. Rumah Tipe A Lamban Pekon Hujung

Tipe A merupakan tipe paling sederhana dengan sistem grid 2 bay atas-bawah. Ruang bawah dengan grid kolom 2 bay yang merupakan ruang kolong panggung, namun kini menjadi ruang penyimpanan hasil pertanian/peternakan atau bahkan sebagai ruang tidur/kamar tambahan, sedangkan ruang atas yang memiliki grid kolom 2 bay merupakan area huni pada rumah ini. Perbedaan juga terlihat pada posisi tangga serta penambahan ruang di bagian depan yang berfungsi sebagai area ruang tamu dalam rumah. 


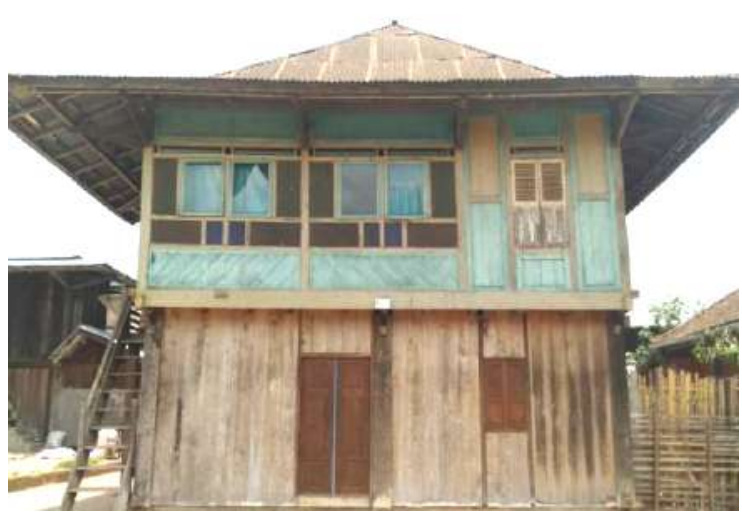

Gambar 2. Rumah Tipe B Lamban Pekon Hujung

Tipe B merupakan tipe dengan sistem grid kolom 2 bay atas dan 3 bay bawah. Secara fungsional sama seperti tipe A, namun perbedaan jumlah bay di bagian atas membuat ruang tengah menjadi lebih luas dibandingkan tipe A. Ruang tengah tersebut biasa difungsikan sebagai ruang keluarga. Perubahan pada tipe ini juga memiliki kemiripan dengan perubahan pada tipe A yakni penambahan ruang depan serta penambahan tangga depan.

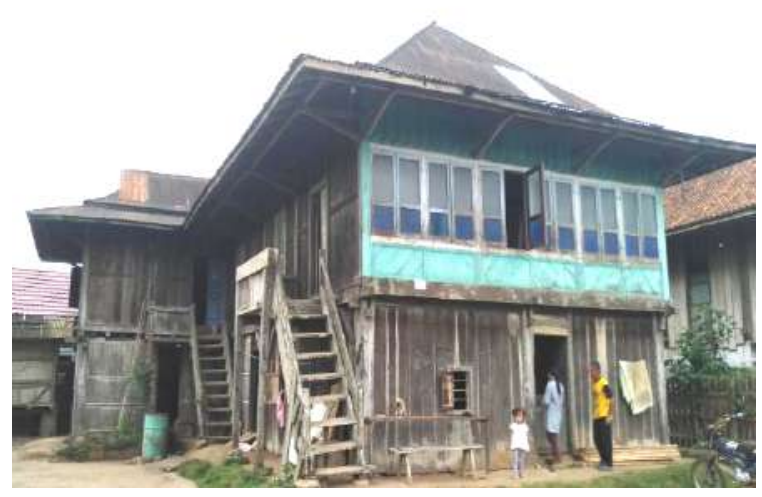

Gambar 3. Rumah Tipe C Lamban Pekon Hujung

Tipe $\mathrm{C}$ merupakan bentuk transformasi dari tipe B dengan sistem grid yang sama yakni 2 bay bawah dan 3 bay atas, namun dengan penambahan teras atas di bagian belakang rumah. Area teras tersebut menjadi ruang entrance tambahan dari rumah, yakni sebagai pintu belakang yang biasanya langsung menuju area dapur. Sedangkan pada bagian depan terdapat perbedaan posisi tangga, dimana tangga depan sebagai tangga utama menjadi akses masuk rumah bagian depan yang menghubungkan ruang luar dengan ruang tamu. Tangga tersebut menghadap ke arah jalan atau ke arah depan rumah.

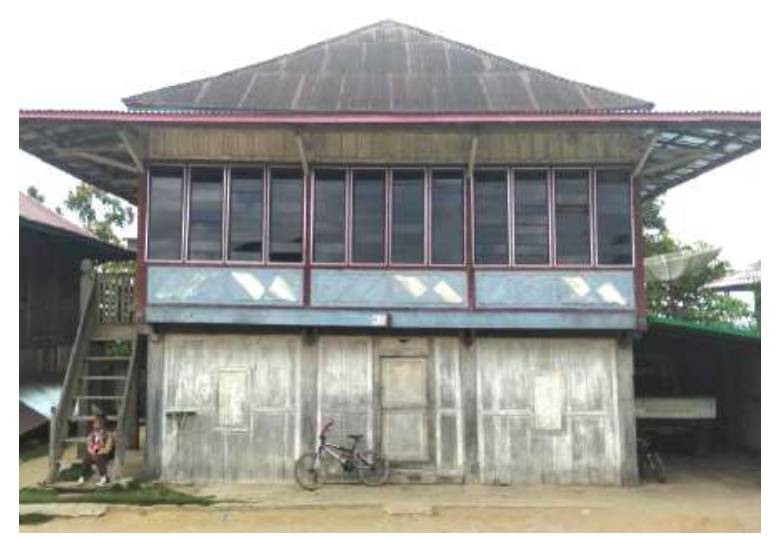

Gambar 4. Rumah Tipe D Lamban Pekon Hujung 
Tipe D merupakan bentuk transformasi dari tipe A dengan menambahkan 1 grid kolom atas-bawah sehingga membentuk pola grid 3 bay atas-bawah. Perubahan pada tipe ini terlihat pada penambahan ruang depan dan perubahan posisi tangga. Transformasi tersebut secara fungsional tetap sama dengan perubahan pada tipe A, namun dengan massa ruang yang lebih besar dan jumlah kamar yang lebih banyak.

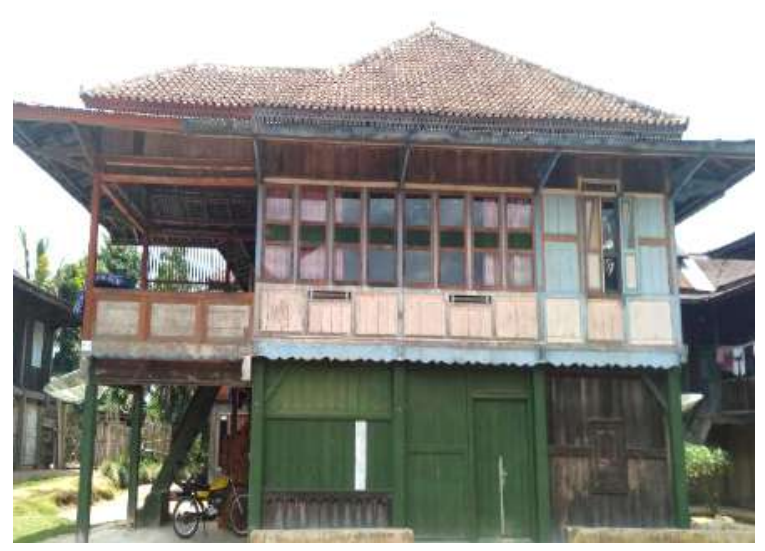

Gambar 5. Rumah Tipe E Lamban Pekon Hujung

Tipe E merupakan bentuk transformasi dari tipe D dengan sistem grid yang sama yakni 3 bay atas-bawah, namun dengan penambahan luasan teras atas pada area tangga depan rumah. Tipe ini juga memiliki beberapa jenis pola perubahan dan penambahan seperti yang terihat pada teras atas yang berada di depan dan belakang sebagai area entrance rumah, jumlah tangga, serta penambahan ruang di sebelah belakang rumah sebagai area service dalam rumah yang biasanya berupa toilet dan dapur.

Dari kelima tipe lamban terlihat perbedaan pada volume atau besaran ruang yang lebih kecil atau lebih besar dari setiap perubahannya. Besaran ruang ditandai dengan penambahan grid kolom yang dilengkapi dengan penambahan tangga, penambahan teras atas, penambahan ruang di bagian depan serta penambahan ruang di bagian belakang rumah. Hasil wawancara menyebutkan bahwa perubahan lamban terjadi karena kebutuhan ruang yang diperlukan anggota keluarga semakin bertambah, perubahan gaya hidup pemilik rumah yang mengikuti perkembangan zaman, ketersediaan material di pasaran yang mempengaruhi penggunaan material bangunan dan tidak lagi mengandalkan material lokal, serta tergantung pada kemampuan pemilik rumah dalam hal finansial untuk melakukan perbaikan/renovasi rumah, penambahan ruang dalam rumah, penambahan atau pengurangan luasan ruang, tanpa mengabaikan aturan adat istiadat yang berlaku di Pekon Hujung.

\section{Kesimpulan}

Hasil penelitian menunjukkan bahwa lamban di Pekon Hujung terbagi dalam 5 tipe rumah dengan 14 jenis grid kolom dengan kemungkinan jumlah grid dapat bertambah seiring bertambahnya kebutuhan penghuni rumah di masa mendatang. Perbandingan dari setiap rumah yang mengalami perubahan dari bentukan dasar ke bentuk baru dan pemenuhan fungsi yang sama, pada dasarnya dipengaruhi oleh kesanggupan finansial/ekonomi pemilik rumah serta besaran luasan kapasitas dari setiap rumah. Perbedaan terlihat pada volume ruang yang lebih kecil atau lebih besar. Hal tersebut ditandai dengan penambahan grid kolom yang dilengkapi dengan penambahan tangga dan teras atas serta ruang di bagian depan atau di bagian belakang rumah. Perbedaan yang ada menjadi bentuk tersendiri yang sama-sama dianggap sebagai bagian dari kebutuhan masyarakat dan tidak melanggar tradisi setempat, karena perubahan yang terjadi tetap memiliki satu kesatuan sebagai ciri khas lamban di Pekon Hujung.

\section{Ucapan Terima Kasih}

Terima kasih dihaturkan kepada Peratin dan seluruh warga Pekon Hujung yang telah menerima rombongan peneliti di Pekon Hujung sekaligus sebagai sumber data utama dalam penelitian ini, kepada bapak ibu dosen Arsitektur dan mahasiswa 161 Arsitektur yang telah berpartisipasi dalam kegiatan kuliah lapangan Arsitektur Vernakular Liwa, kepada Jurusan Teknologi Infrastruktur dan Kewilayahan Institut Teknologi Sumatera yang telah memberikan dukungan penuh dalam pendanaan penelitian ini, serta semua pihak yang tidak dapat disebutkan satupersatu.

\section{Daftar Pustaka}

Moneo, Raphael. (1978). Moneo on Typology Opposition. MIT Press, Massachusetts, Amerika 


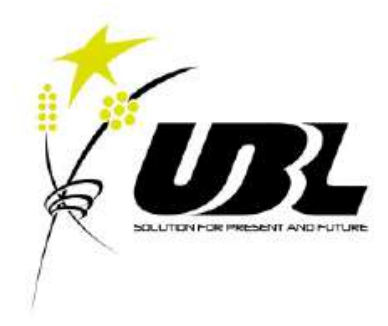

Published:

Program Studi Arsitektur Fakultas Teknik Universitas Bandar Lampung

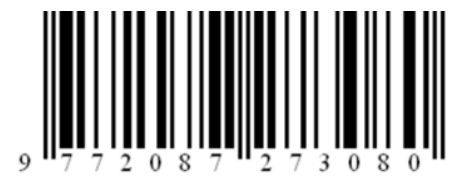

